\title{
Trophic ecology of three dominant myctophid species in the northern California Current region
}

\author{
Andrey V. Suntsov ${ }^{1,2, *}$, Richard D. Brodeur ${ }^{1}$ \\ ${ }^{1}$ Northwest Fisheries Science Center, NOAA Fisheries, 2030 S. Marine Science Drive, Newport, Oregon 97365, USA \\ ${ }^{2}$ Present address: Scripps Institution of Oceanography, 9500 Gilman Drive, La Jolla, California 92093, USA
}

\begin{abstract}
The feeding ecology of 3 dominant sympatric myctophid species (Tarletonbeania crenularis, Diaphus theta, and Stenobrachius leucopsarus) in the northern California Current System was investigated based on samples collected in June, August, and September of 2006. All 3 species fed predominantly on Euphausia pacifica, the most abundant euphausiid off the central Oregon coast. In contrast, the same 3 lanternfishes showed marked variation in utilization of other principal food categories, and stronger resource partitioning was evident in smaller individuals. The proportion of euphausiids in the diet of $T$. crenularis and $S$. leucopsarus gradually increased with increasing size. $D$. theta at intermediate sizes ( 31 to $60 \mathrm{~mm}$ ) preyed heavily upon salps and hyperiid amphipods, whereas the largest specimens consumed mostly euphausiids. S. leucopsarus showed little changes in composition of principal food categories between months, while $T$. crenularis and $D$. theta consumed more hyperiid amphipods in June, euphausiids in August, and salps in September. No feeding on salps was recorded in S. leucopsarus for the entire study period. All 3 species showed variation in feeding intensity, stomach fullness, state of digestion, and number of prey species and prey items per stomach. A divergence in feeding strategies of these co-occurring lanternfishes appears to reflect their structural morphology and generally conforms to an ecological subdivision of this midwater family into 'active' and 'inactive' species. Active myctophids ( $T$. crenularis and $D$. theta) consumed significantly larger amounts of protein-rich prey such as euphausiids, hyperiid amphipods, and salps, while inactive $S$. leucopsarus showed higher preference for slower-moving, lipid-rich Neocalanus copepods.
\end{abstract}

KEY WORDS: Myctophidae ' Mesopelagic - Tarletonbeania crenularis - Diaphus theta . Stenobrachius leucopsarus $\cdot$ Feeding ecology $\cdot$ Ecomorphology $\cdot$ California Current

Resale or republication not permitted without written consent of the publisher -

\section{INTRODUCTION}

The northern California Current (NCC) is a highly productive and dynamic pelagic environment in which significant biophysical variability has been recorded on different time scales from seasonal to decadal (Chelton et al. 1982, McGowan et al. 1998). Primary and secondary production in this region fluctuate dramatically due to episodic variability in upwelling intensity throughout the year (Brickley \& Thomas 2004, Barth et al. 2005) and are also strongly influenced by periodic El Niño and La Niña events and longer-term regime shifts (Peterson \& Schwing 2003). This variability can have pervasive effects on all trophic levels within this system. The region sustains valuable stocks of commercially exploited nektonic species such as salmon, anchovy, sardine, mackerel, albacore, and hake (Brodeur et al. 2003). In addition to these commercial species, a significant portion of the fish biomass in the NCC region is concentrated in what are called micronektonic fishes, i.e. small mesopelagic taxa such as myctophids, gonostomatids, bathylagids, and juvenile pelagic nekton (Brodeur et al. 2005).

Ubiquitous bioluminescent fishes of the family Myctophidae, commonly known as lanternfishes, are often the dominant component of micronektonic communities in the North Pacific, achieving very high abundances and biomass (Beamish et al. 1999, Brodeur \& 
Yamamura 2005). Myctophids represent an important trophic link between phytophagous zooplankton such as copepods and euphausiids and higher trophic level organisms such as salmon, tuna, seabirds, and marine mammals (see review in Brodeur \& Yamamura 2005). They dominate the fish biomass in oceanic waters of the Northeast Pacific (Pearcy 1977, Gjøsaeter \& Kawaguchi 1980, Beamish et al. 1999), and their transport onto continental shelves represents an important flux of energy into these systems, as represented in food web models of the California Current (Field et al. 2006).

Three lanternfish species (Tarletonbeania crenularis, Stenobrachius leucopsarus, and Diaphus theta) form the bulk of micronekton fishes found in the NCC. These 3 species were reported to account for twothirds of all fishes collected in Isaac-Kidd midwater trawl tows in the upper 200 m off Oregon, USA (Pearcy 1964, 1977). Due to their high biomass and widespread distribution and coupled with biological features such as diel vertical migration and strong zooplanktivory, myctophids are widely recognized as significant but poorly understood mediators in the transfer of organic matter from lower to higher trophic levels and to deeper ocean layers (Merrett \& Roe 1974, Williams et al. 2001, Brodeur \& Yamamura 2005). The sheer biomass of these fishes in the NCC clearly implies that they have a vast potential for competition for food resources with other co-occurring commercial fish species such as juvenile rockfishes Sebastes spp. and Pacific hake Merluccius productus, but the extent of such ecological interactions remains poorly understood.

In the North Pacific, feeding preferences and general trophodynamics of various lanternfish species were investigated in low- (Clarke 1973), temperate(Gordon et al. 1985, Moku et al. 2000, Uchikawa et al. 2002, Watanabe et al. 2002), and high-latitude regions (Balanov 1994, Balanov et al. 1995, Nishimura et al. 1999), with more emphasis on the western part of the ocean. Off the coast of Oregon, feeding ecology of the principal myctophid species was studied more than 3 decades ago (Tyler \& Pearcy 1975, Pearcy et al. 1979), and the only recent study examining their diet was a geographically limited investigation in Astoria Canyon off Oregon (Bosley et al. 2004). None of these studies examined aspects of trophic ecology that influence interactions among competing groups such as seasonal changes or diet overlap. Studies of such interactions among these species are needed as part of an attempt to understand broader marine ecological frameworks in the NCC. In the present study, we capitalized on extensive lanternfish collections made off Oregon and Washington to describe diet diversity and variability in 3 dominant myctophid species in the NCC region.

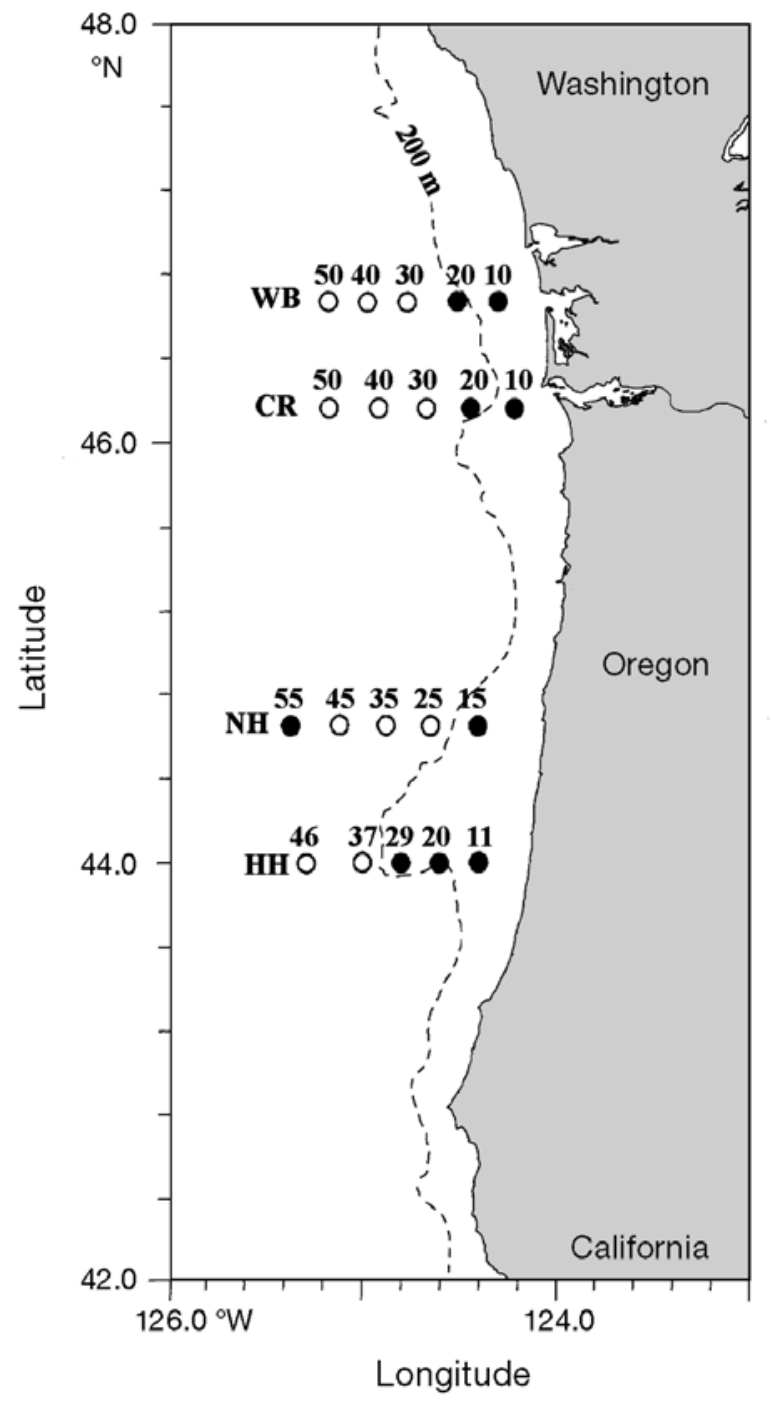

Fig. 1. Transects and stations of the Stock Assessment Improvement Program (SAIP) in 2006. Open circles indicate stations where myctophid specimens used in this study were collected

\section{MATERIALS AND METHODS}

Three lanternfish species were collected in June, August, and September during NOAA Stock Assessment Improvement Program (SAIP) cruises in 2006 off the coast of Oregon and Washington, USA. Specimens were collected along 4 transects perpendicular to the coast (Fig. 1) using a Nordic 264 rope trawl fished at night within the 30 to $50 \mathrm{~m}$ depth stratum. The trawl had an effective mouth opening of $12 \mathrm{~m}$ height and $28 \mathrm{~m}$ width $\left(336 \mathrm{~m}^{2}\right)$ based on net mensuration estimates (Emmett et al. 2004), with a $6.1 \mathrm{~m}$ long, $3 \mathrm{~mm}$ stretched knotless web liner sewn into the cod end. The number of specimens, size range for each species/station, and details of sampling locations are given in Table 1. Trawl samples, initially bulk-frozen at 
sea, were thawed in the lab and sorted. The 3 species of myctophids were initially fixed in a $10 \%$ formalin/ seawater solution and then transferred to $70 \%$ ethanol prior to diet analysis. Specimens for dissection were measured (standard length, SL, $\pm 0.1 \mathrm{~mm}$ ) and weighed $( \pm 0.0001 \mathrm{~g})$.

The stomachs were then removed, placed into a small Petri dish and examined using a dissecting microscope. Prey organisms in the stomachs were identified to the lowest possible taxonomic level and counted. After blotting to remove excess water, wet weights $( \pm 0.0001 \mathrm{~g})$ were obtained for each prey taxon. Stomach fullness was recorded on a scale from 0 to 5 , where $0=$ empty, $1=1 / 4$ full, $2=1 / 2$ full, $3=3 / 4$ full; $4=$ full, and $5=$ distended with thin stomach wall. Even if only 1 small prey item was found, the stomach was classified as category 1 . The state of digestion was determined as $0=$ well digested, 1 = some items identifiable to major categories, $2=$ most items identifiable to major categories, $3=$ some items identifiable to species, $4=$ most or all items identifiable to species.

Diet relationships of the 3 myctophid species were described using percentages for frequency of occurrence $(\mathrm{F})$, number $(\mathrm{Cn})$, and wet weight $(\mathrm{WW})$ of ingested prey. Based on these indices, an Index of Relative Importance (IRI; Pinkas et al. 1971) was calculated as:

$$
\mathrm{IRI}_{\mathrm{i}}=\mathrm{F}_{\mathrm{i}} \times\left(\mathrm{Cn}_{\mathrm{i}}+\mathrm{WW}_{\mathrm{i}}\right)
$$

for each prey category. Feeding intensity was expressed as stomach content index (SCI):
SCI $(\%)=($ WW of stomach contents/body WW $) \times 100$

We used 1-way analyses of variance (ANOVAs) to test for differences in feeding intensity and number of prey items/species per stomach, as well as indices of stomach fullness and state of digestion between different size classes and months.

Trophic relationships between different size groups of myctophids were examined using agglomerative hierarchical cluster analysis applied to a matrix of $\%$ WW contribution of particular prey category (rows) by size class of 1 of 3 lanternfish species (columns). The data matrix was transformed using arcsine square root transformation prior to analysis. We used a Bray-Curtis dissimilarity coefficient and an upper group middle averaging (UPGMA) algorithm to form the dendrograms. Clustering was conducted using Primer v. 5 (Clarke \& Gorley 2001). We also used a multivariate analysis of similarities (ANOSIM) to test for differences in diet based on \% WW of particular prey using different months, size groups, and geographical component (north versus south) as factors. The similarity matrix on WW composition of different prey (arcsine square root transformed) was calculated using Bray-Curtis coefficient and then subjected to ANOSIM analysis using Primer (Clarke \& Green 1988). To determine which prey taxa were most likely responsible for the patterns detected by ANOSIM, we followed with a similarity percentages (SIMPER) analysis to define the discriminating species for each factor.

Table 1. Tarletonbeania crenularis, Stenobrachius leucopsarus, and Diaphus theta. Sampling location information and number and size range $(\mathrm{SL}, \mathrm{mm})$ of myctophid specimens examined. Dates given as $\mathrm{mm} / \mathrm{dd} / \mathrm{yy}$

\begin{tabular}{|c|c|c|c|c|c|c|c|}
\hline \multirow[t]{2}{*}{ Stn } & \multirow[t]{2}{*}{ Date } & \multicolumn{2}{|c|}{ Sampling locality } & \multirow{2}{*}{$\begin{array}{c}\text { Bottom } \\
\text { depth (m) }\end{array}$} & \multirow[b]{2}{*}{ T. crenularis } & \multirow{2}{*}{$\begin{array}{l}\text { No. (size range) } \\
\text { S. leucopsarus }\end{array}$} & \multirow[b]{2}{*}{ D. theta } \\
\hline & & Latitude (N) & Longitude (W) & & & & \\
\hline CR-30 & $6 / 17 / 06$ & $46^{\circ} 9^{\prime} 36^{\prime \prime}$ & $124^{\circ} 40^{\prime} 37^{\prime \prime}$ & 732 & $50(24-57)$ & $104(27-74)$ & $12(35-46)$ \\
\hline CR40 & $6 / 16 / 06$ & $46^{\circ} 9^{\prime} 43^{\prime \prime}$ & $124^{\circ} 55^{\prime} 19^{\prime \prime}$ & 853 & $48(24-73)$ & - & - \\
\hline CR-30 & $8 / 10 / 06$ & $46^{\circ} 9^{\prime} 36^{\prime \prime}$ & $124^{\circ} 40^{\prime} 37^{\prime \prime}$ & 732 & - & - & $1(52)$ \\
\hline CR-40 & $8 / 8 / 06$ & $46^{\circ} 9^{\prime} 43^{\prime \prime}$ & $124^{\circ} 55^{\prime} 19^{\prime \prime}$ & 853 & $32(27-71)$ & - & \\
\hline $\mathrm{HH}-37$ & $8 / 8 / 06$ & $44^{\circ} 0^{\prime} 7^{\prime \prime}$ & $125^{\circ} 0^{\prime} 0^{\prime \prime}$ & 950 & - & $38(36-70)$ & $69(40-67)$ \\
\hline $\mathrm{NH}-25$ & $8 / 9 / 06$ & $33^{\circ} 38^{\prime} 60^{\prime \prime}$ & $124^{\circ} 39^{\prime} 7^{\prime \prime}$ & 297 & - & & $8(44-68)$ \\
\hline NH-35 & $8 / 9 / 06$ & $44^{\circ} 39^{\prime} 7^{\prime \prime}$ & $124^{\circ} 52^{\prime} 48^{\prime \prime}$ & 435 & $15(32-64)$ & $37(18-47)$ & - \\
\hline $\mathrm{NH}-45$ & $8 / 8 / 06$ & $44^{\circ} 39^{\prime} 11^{\prime \prime}$ & $125^{\circ} 7^{\prime} 5^{\prime \prime}$ & 700 & - & $18(34-46)$ & $1(46)$ \\
\hline CR-30 & 8/10/06 & $46^{\circ} 9^{\prime} 36^{\prime \prime}$ & $124^{\circ} 40^{\prime} 37^{\prime \prime}$ & 732 & $25(30-71)$ & - & - \\
\hline WB-30 & 8/11/06 & $46^{\circ} 40^{\prime} 5^{\prime \prime}$ & $124^{\circ} 46^{\prime} 41^{\prime \prime}$ & 293 & $27(31-76)$ & $10(32-45)$ & $10(46-70)$ \\
\hline WB-40 & 8/10/06 & $46^{\circ} 40^{\prime} 1^{\prime \prime}$ & $124^{\circ} 58^{\prime} 55^{\prime \prime}$ & 910 & $16(29-70)$ & - & - \\
\hline $\mathrm{HH}-37$ & $9 / 25 / 06$ & $44^{\circ} 0^{\prime} 7^{\prime \prime}$ & $125^{\circ} 0^{\prime} 0^{\prime \prime}$ & 950 & $10(43-65)$ & $5(39-73)$ & $18(19-63)$ \\
\hline $\mathrm{HH}-46$ & $9 / 25 / 06$ & $43^{\circ} 59^{\prime} 49^{\prime \prime}$ & $125^{\circ} 17^{\prime} 13^{\prime \prime}$ & 1600 & $10(47-70)$ & - & $15(19-22)$ \\
\hline $\mathrm{NH}-45$ & $9 / 25 / 06$ & & & 700 & $16(39-79)$ & $11(30-48)$ & $1(54)$ \\
\hline NH-35 & 9/26/06 & $44^{\circ} 39^{\prime} 7^{\prime \prime}$ & $124^{\circ} 52^{\prime} 48^{\prime \prime}$ & 435 & $5(46-68)$ & $3(43-49)$ & $1(56)$ \\
\hline CR-30 & 9/27/06 & $46^{\circ} 9^{\prime} 36^{\prime \prime}$ & $124^{\circ} 40^{\prime} 37^{\prime \prime}$ & 732 & $10(44-75)$ & $10(43-73)$ & $10(43-57)$ \\
\hline CR-40 & 9/27/06 & $46^{\circ} 9^{\prime} 43^{\prime \prime}$ & $124^{\circ} 55^{\prime} 19^{\prime \prime}$ & 853 & $10(41-80)$ & $9(41-54)$ & $19(38-59)$ \\
\hline CR-50 & 9/27/06 & $46^{\circ} 9^{\prime} 43^{\prime \prime}$ & $124^{\circ} 10^{\prime} 41^{\prime \prime}$ & 1423 & $44(28-70)$ & $52(18-67)$ & $32(20-58)$ \\
\hline WB-40 & 9/27/06 & $46^{\circ} 40^{\prime} 1^{\prime \prime}$ & $124^{\circ} 58^{\prime} 55^{\prime \prime}$ & 910 & $9(43-64)$ & $6(40-67)$ & $12(36-56)$ \\
\hline WB-50 & 9/29/06 & $46^{\circ} 40^{\prime} 12^{\prime \prime}$ & $124^{\circ} 10^{\prime} 59^{\prime \prime}$ & 1020 & - & - & $10(40-57)$ \\
\hline
\end{tabular}




\section{RESULTS}

In total, stomach contents of 328 Tarletonbeania crenularis, 219 Diaphus theta, and 303 Stenobrachius leucopsarus were analyzed (Table 1). These 3 species overlapped broadly in their length-frequency distributions and had similar length-weight relationships (Fig. 2). In general, feeding incidence was high, with the number of full or partially full stomachs being highest in $D$. theta $(96.6 \%)$ lowest in $T$. crenularis $(86.9 \%)$, and intermediate in S. leucopsarus $(90.4 \%)$.

The specimens of Tarletonbeania crenularis, ranging from 24 to $80 \mathrm{~mm} \mathrm{SL}$, yielded 4592 food items spread over 29 prey categories (Table 2). Food of $T$. crenularis consisted primarily of euphausiids $(70.0 \%$ WW), which, along with hyperiid amphipods (13.3\%), salps $(9.9 \%)$, and larvaceans $(3.2 \%)$, comprised over $95 \%$ of the total food items consumed. Euphausiids were also the most frequently found items, followed by hyperiid amphipods, copepods, appendicularians, and salps. Minor prey categories of $T$. crenularis included ostracods, pteropods, and fish remains, which generally occurred at low frequencies (Table 2). Of the taxa identified to species, copepods displayed the highest species richness (11 species), followed by hyperiid amphipods (5 species). Based on overall IRI calculations, the most significant prey for $T$. crenularis were Euphausia pacifica (IRI 3532), Oikopleura spp. (1173),

\section{a}
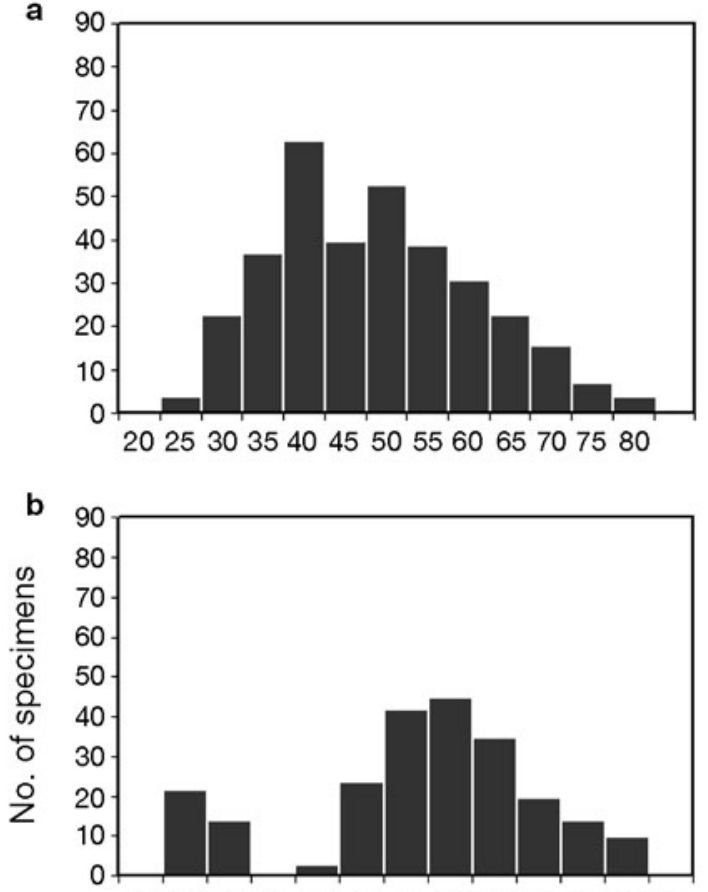

15202530354045505560657075

C

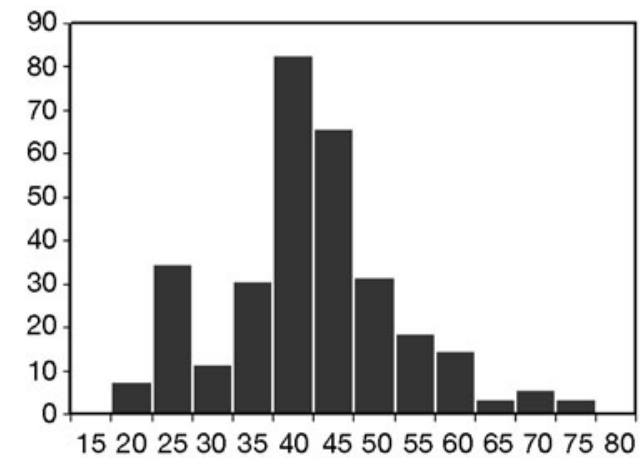

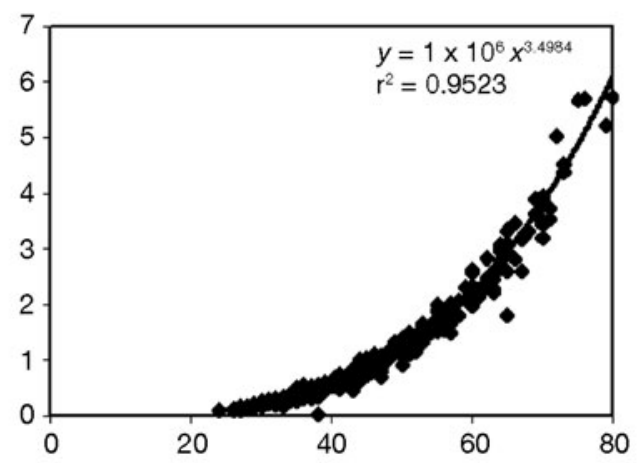
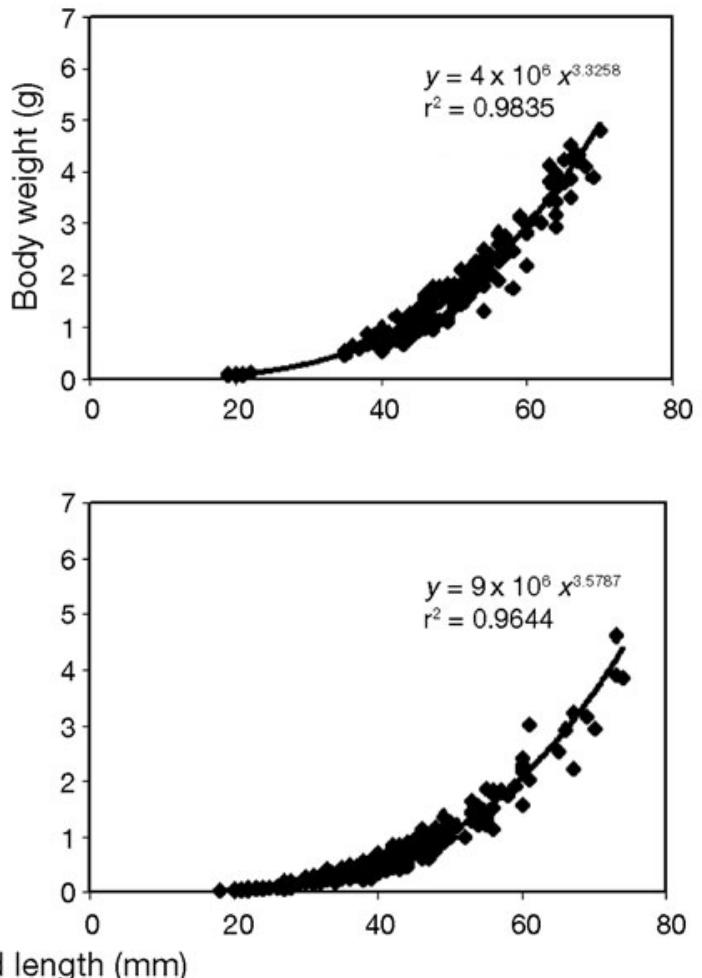

Fig. 2. Tarletonbeania crenularis, Diaphus theta, and Stenobrachius leucopsarus. Length-frequency distributions (left panels) and length-weight relationships (right panels) of (a) T. crenularis, (b) D. theta, (c) S. leucopsarus examined for stomach analysis 
Table 2. Tarletonbeania crenularis, Diaphus theta, and Stenobrachius leucopsarus. Diet composition at all stations combined. See 'Materials and methods' for abbreviations

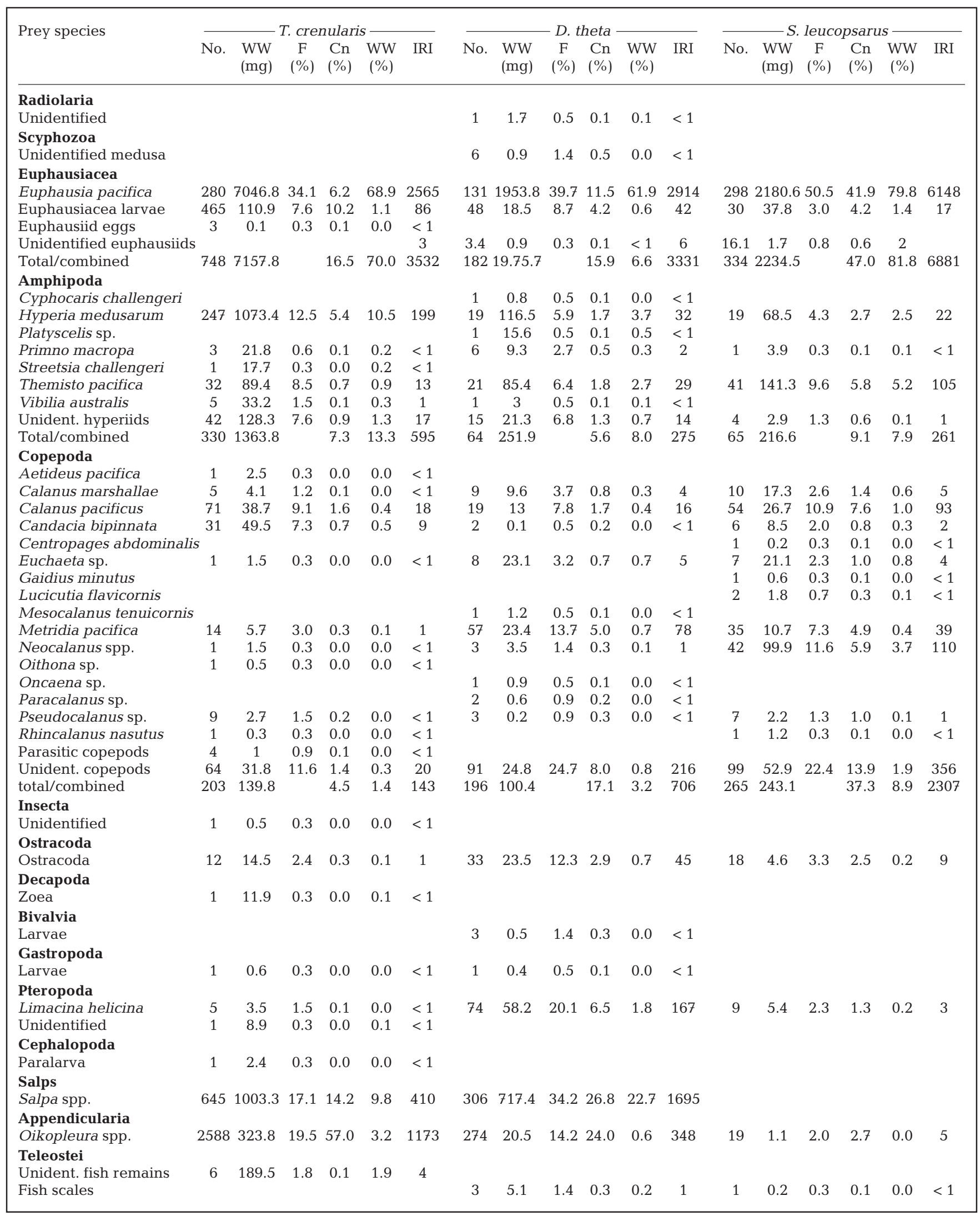


hyperiid amphipods (595), Salpa spp. (410), and copepods (143), whereas the IRI for other zooplankton categories was mostly $<1$ (Table 2 ).

Twenty-five different types of prey from 1143 total identified food items were recorded from specimens of Diaphus theta that ranged from 19 to $70 \mathrm{~mm}$ SL. Various stages of Euphausia pacifica comprised over half of the total prey weight $(62.6 \%)$, followed by Salpa spp. $(22.7 \%)$ and hyperiid amphipods (8.3\%), with the remaining prey categories totaling less than $9 \%$ (Table 2). Copepods were the most frequently found items, followed by euphausiids, salps, pteropods, hyperiids, appendicularians, and ostracods. Copepods were also the most diverse prey category (at least 10 species), with Calanus pacificus, C. marshallae, and Metridia pacifica occurring most frequently. At least 5 species of hyperiid amphipods were recorded in the diet of $D$. theta, with Hyperia medusarum and Themisto pacifica being dominant both by biomass and frequency of occurrence. The most significant prey types for D. theta were E. pacifica (IRI 2914) and Salpa spp. (1695), followed by copepods (706), Oikopleura spp. (348), hyperiid amphipods (275), and Limacina helicina (167; Table 2).

Twenty-two prey categories were identified in specimens of Stenobrachius leucopsarus in the 18 to $74 \mathrm{~mm}$ SL size range. The diet of this species consisted mainly of Euphausia pacifica (77.8\%), and hyperiid amphipods $(7.9 \%)$, with the remaining categories comprising $<15 \%$. The most frequently consumed prey were $E$. pacifica, copepods, and hyperiids, with the 2 latter categories also being the most diverse prey. IRI calculations indicated overall importance of just 2 main prey types, euphausiids (IRI: 6880) and copepods (2307) in the diet of $S$. leucopsarus (Table 2).

\section{Ontogenetic changes in major diet categories}

There was a strong tendency of Tarletonbeania crenularis toward reliance on just 1 type of prey, namely Euphausia pacifica, with increasing size (Fig. 3). The proportion of this prey in diets steadily increased from $20 \%$ in specimens $24-30 \mathrm{~mm}$ SL to $88 \%$ at $71-80 \mathrm{~mm}$ SL. The utilization of hyperiid amphipods showed the opposite trend. Hyperiid amphipods comprised up to $39 \%$ of WW biomass at 31-40 $\mathrm{mm}$, but this proportion decreased to less than $2 \%$ in specimens $61-70 \mathrm{~mm}$. At $20-40 \mathrm{~mm} \mathrm{SL}$, the WW biomass values for hyperiid amphipods were greater than for any other large prey category, being exceeded only by E. pacifica at larger sizes. A less pronounced decrease was evident in the consumption of salps with growth in T. crenularis. In general, the smallest specimens of $T$. crenularis fed heavily on salps, whose

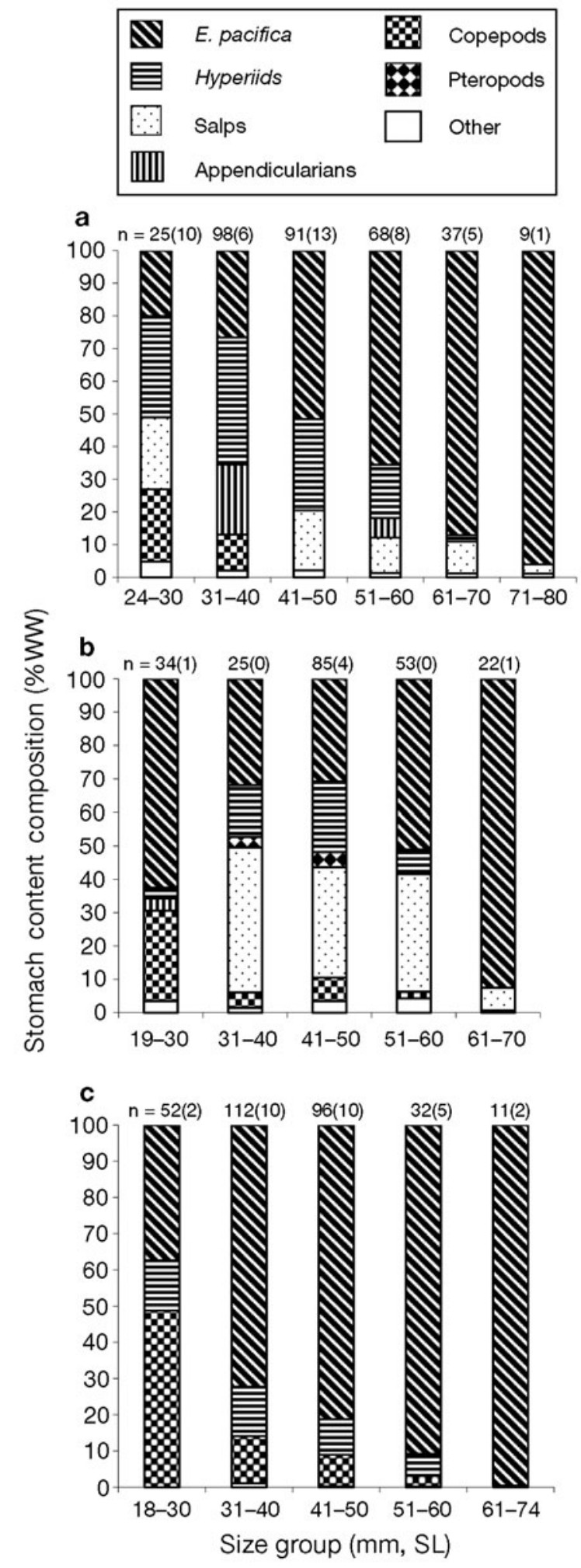

Fig. 3. Tarletonbeania crenularis, Diaphus theta, and Stenobrachius leucopsarus. Wet weight composition (\% WW) of prey categories for different size groups in 3 myctophid species: (a) T. crenularis, (b) D. theta, (c) S. leucopsarus. The number of stomachs analyzed and the number of empty stomachs (in parentheses) is shown at the top of each graph 
dietary contribution was identical to that of copepods. Unlike salps, which were consumed in detectable quantities even by the largest $T$. crenularis, copepods were only important for fish $<40 \mathrm{~mm}$ and were found in negligible numbers in stomachs of larger specimens. The larvacean Oikopleura sp. was an important prey for $2 T$. crenularis size categories: $31-40 \mathrm{~mm}(21.0 \%$ WW) and 51-60 mm (6.0\%), but contributed less than $2 \%$ to the diet of other size categories.

The ontogenetic diet shift in Stenobrachius leucopsarus was generally similar to that in Tarletonbeania crenularis in that there was a clear increase in the consumption of Euphausia pacifica with increasing predator size. However, the dependence on E. pacifica with increasing predator size was even more pronounced for this species, where even at a size of 31-40 mm, euphausiids already comprised over $70 \%$ of the prey weight. Both hyperiid amphipods and copepods showed a clear decrease in WW percentages with growth of this species. Almost half of the diet (49\%) in the smallest specimens of $S$. leucopsarus (18-30 mm SL) was composed of copepods (Fig. 3).

Diaphus theta showed a different pattern of diet change with increasing size. Unlike the other 2 species, its smallest size group (19-30 mm) fed heavily on small euphausiids (62\%) and copepods (27\%). However, reliance on Euphausia pacifica decreased at 31-60 mm, when this species started to consume large quantities of salps, with their dietary contribution ranging from 33 to $43 \% \mathrm{WW}$. The amount of hyperiid amphipods consumed by $D$. theta also peaked at these sizes, but the contribution of copepods was minor (2.0 to $7.1 \%$ ). Among other major prey categories, the pteropod Limacina helicina was important in D. theta diets at sizes of $31-50 \mathrm{~mm}$ (3.1 to $4.5 \% \mathrm{WW}$ ), while Oikopleura spp. had a contribution similar to hyperiid amphipods consumed by specimens 19-30 mm SL (Fig. 3).

\section{Between-month variability in major diet categories}

Among the 3 myctophid species, Euphausia pacifica appeared to be the most important prey type for Stenobrachius leucopsarus, and its \%WW in the fish stomachs remained practically unchanged for all 3 months, ranging from 77 to $87 \%$, with higher values recorded in August. Tarletonbeania crenularis and Diaphus theta also consumed a higher percentage of E. pacifica during August than in other months. In June and September, however, the role of E. pacifica in the diet of $D$. theta was reduced relative to other types of prey (Fig. 4).

Hyperiid amphipods were more important prey for all 3 myctophids in early summer, with dietary contribution

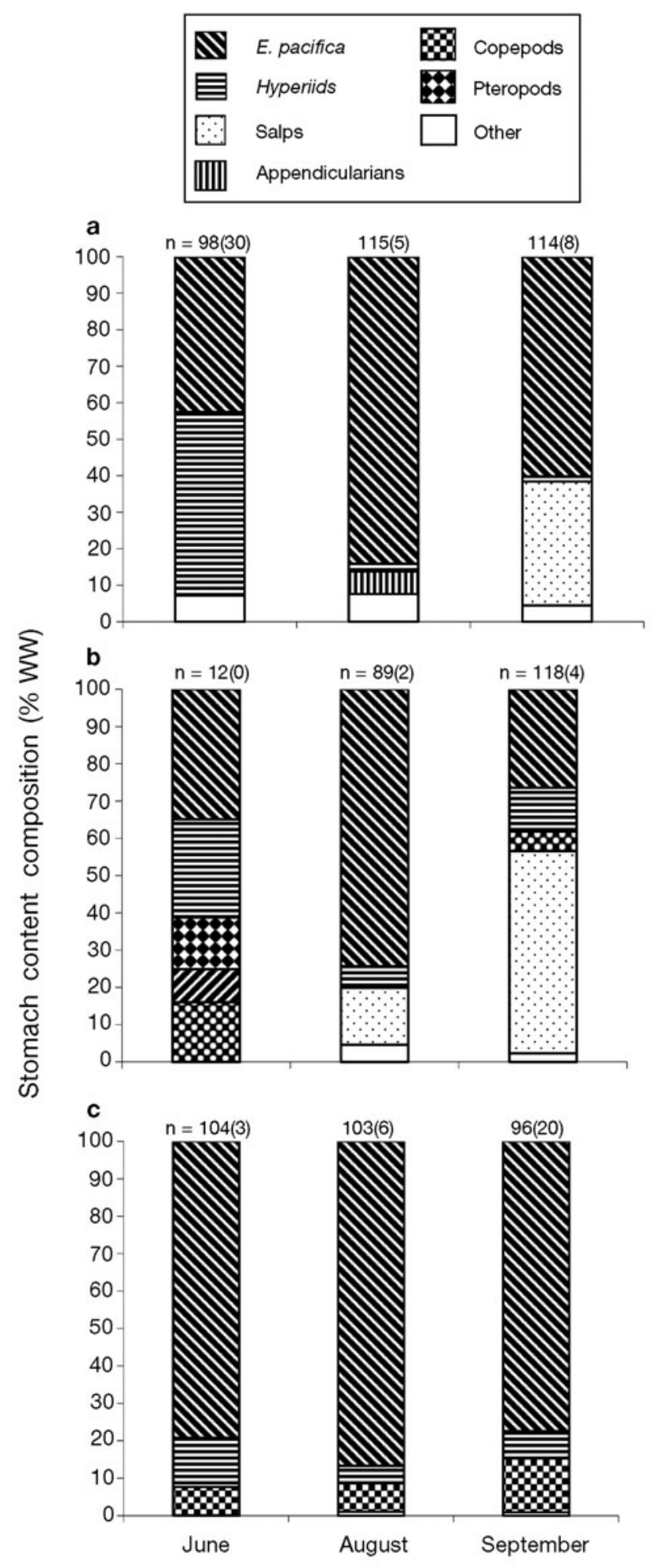

Fig. 4. Tarletonbeania crenularis, Diaphus theta, and Stenobrachius leucopsarus. Between-month variation in different prey categories (\% WW) in 3 myctophid species: (a) T. crenularis, (b) D. theta, (c) S. leucopsarus. The number of stomachs analyzed and number of empty stomachs (in parentheses) is shown at the top of each graph 
ranging from $13.5 \%$ in Stenobrachius leucopsarus to $50.3 \%$ in Tarletonbeania crenularis. In the following months, the proportion of hyperiid amphipods dropped most significantly in T. crenularis (to $2.1 \%$ in August and $1.5 \%$ in September), but these prey were still important for Diaphus theta (11.7\% in September). Overall variations in hyperiid amphipod consumption were least pronounced in $S$. leucopsarus. This species fed more on hyperiids in June (13.2\%) and September (7.3\%), but less in August (4.7\%). A somewhat similar pattern was evident for $D$. theta, with the highest proportion of hyperiids consumed in June, lowest in August, and intermediate values recorded in September (Fig. 4).

Throughout the study period, calanoid copepods did not play a significant role in the diet of Tarletonbeania crenularis. For Diaphus theta, however, copepods were somewhat important prey, increasing to $16.0 \%$ of total prey biomass in early summer, and then decreasing to less than $2 \%$ in August before slightly increasing again in September (5.3\%). Variations in copepod biomass were much less pronounced in Stenobrachius leucopsarus, with nearly equal proportions consumed in June and August, and a doubling of those proportions in September.

Gelatinous zooplankters (Salpa spp.) were recorded as the most significant prey for Diaphus theta. Their most intense feeding on salps occurred during September, when salp biomass exceeded $50 \%$ of total zooplankton consumed. A lower proportion of salps $(15.3 \%)$ was eaten by D. theta during August, and no salps were found in specimens collected during June. A similar feeding pattern was found in Tarletonbeania crenularis, with 1 Salpa sp. specimen recorded in June, 37 in August, and 607 in September, when salps comprised $33.9 \%$ of the biomass of all ingested prey (Fig. 4). Unlike the other 2 myctophids, Stenobrachius leucopsarus did not feed on salps during the months investigated.

\section{Feeding differences between size classes}

With the exception of the largest specimens of Stenobrachius leucopsarus (61-74 mm SL), which showed high dissimilarity to all other specimens (possibly due to the small sample size), 3 distinct clusters were formed at a similarity of about $50 \%$ (Fig. 5). The bulk of S. leucopsarus specimens (18-60 mm SL) formed a cluster with Tarletonbeania crenularis (31-40 mm) and Diaphus theta (19-30 mm). Close grouping of most sizes of $S$. leucopsarus appeared to be a result of its less diverse diet, which did not include Salpa spp. or any significant amounts of Oikopleura and Limacina. Smaller specimens of $D$. theta $(19-30 \mathrm{~mm})$ and $T$. crenularis (31-40 mm SL), joining at a level of about $62 \%$ similarity, both fed on appendicularians, which comprised up to $21 \% \mathrm{WW}$ of biomass for T. crenularis at that size range. Similar to $S$. leucopsarus, D. theta and $T$. crenularis at this size did not consume any significant amounts of salps.

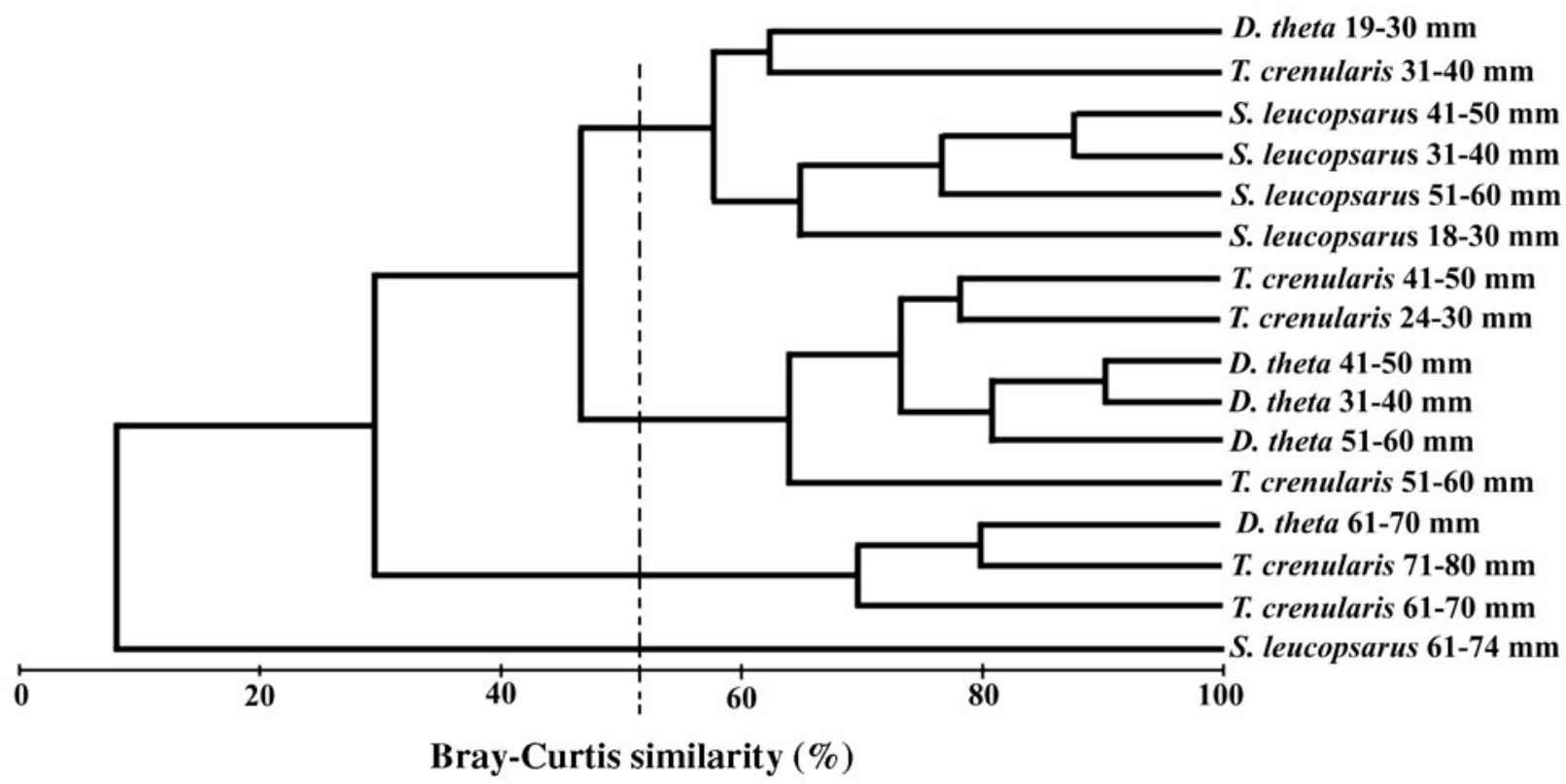

Fig. 5. Tarletonbeania crenularis, Diaphus theta, and Stenobrachius leucopsarus. Feeding differences between different size classes of 3 myctophid species based on WW composition (\%) of prey categories. Dashed line indicates cut-off level for groups discussed in text 
Another cluster was formed by a mixture of mediumsized Diaphus theta (31-60 mm SL) and Tarletonbeania crenularis specimens (24-30 and 41-60 mm SL). The higher similarity among $D$. theta at these size classes was likely the result of its more varied diet, which included a substantial proportion of gelatinous zooplankton (mainly Salpa spp.), with remaining food categories more evenly spread. T. crenularis also consumed a significant proportion of salps at these sizes.

Finally, 1 small cluster included the largest specimens of Tarletonbeania crenularis (61-80 mm) and Diaphus theta (61-70 mm). Euphausia pacifica was the dominant food item for fish at that size, ranging from 88 to $92 \%$ WW of prey biomass. In addition, these large $T$. crenularis and $D$. theta groups continued to feed on salps, the proportion of which ranged from 3 to $10 \%$ of the diet of these size groups.

\section{Analysis of dietary variability}

Based on ANOSIM analyses, the diets of Tarletonbeania crenularis differed significantly among all 3 months, but the diet of Diaphus theta was significantly different only between August and September; feeding by Stenobrachius leucopsarus differed significantly between June and the 2 other months. In terms of geographical variation, the diets of only 2 species, $D$. theta and $S$. leucopsarus, differed significantly between the 2 northern and 2 southern transects. Between-group dissimilarities were generally higher for T. crenularis and D. theta than for S. leucopsarus (Table 3). In all 3 species, euphausiids accounted for major differences in feeding among different areas and months. Euphausiids were also principal contributors to the differences observed among all size groups

Table 3. Tarletonbeania crenularis, Diaphus theta, and Stenobrachius leucopsarus. Pairwise ANOSIM comparisons of myctophid diet (\% WW) for different size groups, months, and geographical regions in 3 species of myctophids. Significant values are in bold

\begin{tabular}{|c|c|c|c|c|c|c|c|c|}
\hline T. crenularis & $24-30 \mathrm{~mm}$ & $31-40 \mathrm{~mm}$ & $41-50 \mathrm{~mm}$ & $51-60 \mathrm{~mm}$ & $61-70 \mathrm{~mm}$ & June & August & North \\
\hline \multicolumn{9}{|l|}{$24-30 \mathrm{~mm}$} \\
\hline $31-40 \mathrm{~mm}$ & 0.15 & & & & & & & \\
\hline $41-50 \mathrm{~mm}$ & 0.04 & 0.001 & & & & & & \\
\hline $51-60 \mathrm{~mm}$ & 0.11 & 0.001 & 0.06 & & & & & \\
\hline $61-70 \mathrm{~mm}$ & 0.002 & 0.001 & 0.03 & 0.81 & & & & \\
\hline $71-80 \mathrm{~mm}$ & 0.02 & 0.001 & 0.05 & 0.47 & 0.35 & & & \\
\hline \multicolumn{9}{|l|}{ June } \\
\hline August & & & & & & 0.001 & & \\
\hline September & & & & & & 0.001 & 0.001 & \\
\hline South & & & & & & & & 0.3 \\
\hline D. theta & $19-30 \mathrm{~mm}$ & $31-40 \mathrm{~mm}$ & $41-50 \mathrm{~mm}$ & $51-60 \mathrm{~mm}$ & $61-70 \mathrm{~mm}$ & June & August & North \\
\hline \multicolumn{9}{|l|}{$19-30 \mathrm{~mm}$} \\
\hline $31-40 \mathrm{~mm}$ & 0.01 & & & & & & & \\
\hline $41-50 \mathrm{~mm}$ & 0.009 & 0.54 & & & & & & \\
\hline $51-60 \mathrm{~mm}$ & 0.001 & 0.32 & 0.53 & & & & & \\
\hline $61-70 \mathrm{~mm}$ & 0.001 & 0.006 & 0.01 & 0.01 & & & & \\
\hline \multicolumn{9}{|l|}{ June } \\
\hline August & & & & & & 1 & & \\
\hline September & & & & & & 0.93 & 0.002 & \\
\hline South & & & & & & & & 0.001 \\
\hline S. leucopsarus & $18-30 \mathrm{~mm}$ & $31-40 \mathrm{~mm}$ & $41-50 \mathrm{~mm}$ & $51-60 \mathrm{~mm}$ & $61-70 \mathrm{~mm}$ & June & August & North \\
\hline \multicolumn{9}{|l|}{$18-30 \mathrm{~mm}$} \\
\hline $31-40 \mathrm{~mm}$ & 0.001 & & & & & & & \\
\hline $41-50 \mathrm{~mm}$ & 0.001 & 0.07 & & & & & & \\
\hline $51-60 \mathrm{~mm}$ & 0.001 & 0.01 & 0.06 & & & & & \\
\hline $61-70 \mathrm{~mm}$ & 0.003 & 0.3 & 0.6 & 0.8 & & & & \\
\hline $71-80 \mathrm{~mm}$ & 0.03 & 0.6 & 0.7 & 0.6 & 0.3 & & & \\
\hline \multicolumn{9}{|l|}{ June } \\
\hline August & & & & & & 0.001 & & \\
\hline September & & & & & & 0.001 & 0.06 & \\
\hline South & & & & & & & & 0.001 \\
\hline
\end{tabular}


of $S$. leucopsarus. This overall pattern was also prevalent in the 2 other myctophid species, but salps contributed more to dissimilarities in feeding of mid-sized D. theta (31-60 mm), and hyperiid amphipods were the major contributor to differences in diet among small T. crenularis (31-40 and 24-30 mm SL; Table 4).

\section{Variations in feeding intensity and diet diversity}

Feeding intensity (\% BW) in Tarletonbeania crenularis showed substantial variation, decreasing from $3.7 \%$ in June to $1.9 \%$ in September; this species showed the highest feeding intensity among the 3 species examined. Moderate changes were observed for the mean number of prey items ingested (10.5 to 25.1), while monthly variation in the number of prey species (1.7 to 2.0) consumed was not significant. Stomach fullness index showed the highest values in August, while state of digestion steadily decreased with time; both of these parameters showed significant changes between months (Table 5).

Diaphus theta showed the lowest values of feeding intensity (1.2 to $1.4 \%$ BW) among the 3 myctophid species. On the other hand, the overall diet of this species was more diverse with mean numbers of prey species

Table 4. Tarletonbeania crenularis, Diaphus theta, and Stenobrachius leucopsarus. Results of SIMPER analysis of myctophid prey composition (\% WW) showing dissimilarities values between size groups, months, and geographical regions. Prey codes refer to the taxa that account for the most difference. Hyper: hyperiids. Taxa other than euphausiids (Euph) are in bold

\begin{tabular}{|c|c|c|c|c|c|c|c|c|c|c|c|}
\hline T. crenularis & $\begin{array}{c}24-30 \\
\mathrm{~mm}\end{array}$ & $\begin{array}{c}31-40 \\
\mathrm{~mm}\end{array}$ & $\begin{array}{c}41-50 \\
\mathrm{~mm}\end{array}$ & $\begin{array}{c}51-60 \\
\mathrm{~mm}\end{array}$ & $\begin{array}{c}61-70 \\
\mathrm{~mm}\end{array}$ & $\begin{array}{c}71-80 \\
\mathrm{~mm}\end{array}$ & June & August & September & North & South \\
\hline $24-30 \mathrm{~mm}$ & & Hyper & Euph & Euph & Euph & Euph & & & & & \\
\hline $31-40 \mathrm{~mm}$ & 79.7 & & Euph & Euph & Euph & Euph & & & & & \\
\hline $41-50 \mathrm{~mm}$ & 79.3 & 82.9 & & Euph & Euph & Euph & & & & & \\
\hline $51-60 \mathrm{~mm}$ & 85.1 & 86.4 & 76.8 & & Euph & Euph & & & & & \\
\hline $61-70 \mathrm{~mm}$ & 89.5 & 89.8 & 76.5 & 75.7 & & Euph & & & & & \\
\hline $71-80 \mathrm{~mm}$ & 91.1 & 92.7 & 81.9 & 80.5 & 72.3 & & & & & & \\
\hline June & & & & & & & & Euph & Euph & & \\
\hline August & & & & & & & 83.1 & & Euph & & \\
\hline September & & & & & & & 82.7 & 84.2 & & & \\
\hline North & & & & & & & & & & & Euph \\
\hline South & & & & & & & & & & 81.5 & \\
\hline D. theta & $\begin{array}{c}19-30 \\
\mathrm{~mm}\end{array}$ & $\begin{array}{c}31-40 \\
\mathrm{~mm}\end{array}$ & $\begin{array}{c}41-50 \\
\mathrm{~mm}\end{array}$ & $\begin{array}{c}51-60 \\
\mathrm{~mm}\end{array}$ & $\begin{array}{c}61-70 \\
\mathrm{~mm}\end{array}$ & $\begin{array}{c}71-80 \\
\mathrm{~mm}\end{array}$ & June & August & September & North & South \\
\hline $19-30 \mathrm{~mm}$ & & Euph & Euph & Euph & Euph & & & & & & \\
\hline $31-40 \mathrm{~mm}$ & 84 & & Salps & Salps & Euph & & & & & & \\
\hline $41-50 \mathrm{~mm}$ & 79.9 & 78 & & Salps & Euph & & & & & & \\
\hline $51-60 \mathrm{~mm}$ & 81.9 & 79.9 & 79.2 & & Euph & & & & & & \\
\hline $61-70 \mathrm{~mm}$ & 80.3 & 86.8 & 84.2 & 83.6 & & & & & & & \\
\hline June & & & & & & & & Euph & Euph & & \\
\hline August & & & & & & & 74.1 & & Euph & & \\
\hline September & & & & & & & 76.4 & 81.9 & & & \\
\hline North & & & & & & & & & & & Euph \\
\hline South & & & & & & & & & & 81.4 & \\
\hline S. leucopsarus & $\begin{array}{c}18-30 \\
\mathrm{~mm}\end{array}$ & $\begin{array}{c}31-40 \\
\mathrm{~mm}\end{array}$ & $\begin{array}{c}41-50 \\
\mathrm{~mm}\end{array}$ & $\begin{array}{c}51-60 \\
\mathrm{~mm}\end{array}$ & $\begin{array}{c}61-70 \\
\mathrm{~mm}\end{array}$ & $\begin{array}{c}71-80 \\
\mathrm{~mm}\end{array}$ & June & August & September & North & South \\
\hline $18-30 \mathrm{~mm}$ & Euph & Euph & Euph & Euph & Euph & & & & & & \\
\hline $31-40 \mathrm{~mm}$ & 69.4 & & Euph & Euph & Euph & Euph & & & & & \\
\hline $41-50 \mathrm{~mm}$ & 74.8 & 62.9 & & Euph & Euph & Euph & & & & & \\
\hline $51-60 \mathrm{~mm}$ & 79.1 & 69.8 & 66.8 & & Euph & Euph & & & & & \\
\hline $61-70 \mathrm{~mm}$ & 80.8 & 64.8 & 58.4 & 59.4 & & Euph & & & & & \\
\hline $71-80 \mathrm{~mm}$ & 87.15 & 59.2 & 52.3 & 61.7 & 42.41 & & & & & & \\
\hline June & & & & & & & & Euph & Euph & & \\
\hline August & & & & & & 68.8 & & Euph & & & \\
\hline September & & & & & 70 & 69.9 & & & & & \\
\hline North & & & & & & & & & & & Euph \\
\hline South & & & & & & & & & & 68.3 & \\
\hline
\end{tabular}


ranging from 2.0 to 4.4 and decreasing significantly with time. Compared to Tarletonbeania crenularis and Stenobrachius leucopsarus, total numbers of prey items for $D$. theta were intermediate, with minimal variation among months. Indices for stomach fullness and digestive state showed a significant decrease with increasing size.

Both the total number of prey items and prey species richness decreased from June to September in Stenobrachius leucopsarus, with highly significant variations. The number of prey items per stomach in $S$. leucopsarus was lowest among the 3 myctophid species, with mean values ranging from 1.7 to 3.7. Mean numbers of prey species consumed by $S$. leucopsarus were also low compared to the other 2 myctophid species and ranged from 1.3 to 1.9 . Stomach fullness and state of digestion values also varied significantly between months, with both of these parameters decreasing steadily with time. On the other hand, changes in $\%$ BW were minimal and not significant for S. leucopsarus (Table 5).

Among 6 different size classes of Tarletonbeania crenularis, no significant variation in feeding intensity or number of prey items ingested was observed. Stomach fullness indices also showed no marked change; however, significant variation was detected in the number of prey species, which was somewhat greater at smaller sizes, and in the state of digestion, which had higher values in larger size classes (Table 6).

Table 5. Tarletonbeania crenularis, Diaphus theta, and Stenobrachius leucopsarus. Monthly variation in feeding parameters (mean $\pm \mathrm{SD}$ ). SCI: stomach content index, ns: not significant

\begin{tabular}{|lccccc}
\hline & June & August & September & p \\
\hline T. crenularis & & & & \\
SCI (\% BW) & $3.7 \pm 3.4$ & $2.5 \pm 2.9$ & $1.9 \pm 2.2$ & $<0.0005$ \\
No. of prey items per stomach & $12.1 \pm 17.5$ & $25.1 \pm 46.4$ & $10.5 \pm 13.0$ & $<0.005$ \\
No. of prey species per stomach & $1.8 \pm 0.8$ & $2.0 \pm 1.1$ & $1.7 \pm 0.9$ & $\mathrm{~ns}$ \\
Stomach fullness & $2.5 \pm 2.1$ & $3.0 \pm 1.4$ & $2.5 \pm 1.4$ & $<0.05$ \\
State of digestion & $3.1 \pm 0.8$ & $2.9 \pm 0.9$ & $2.7 \pm 1.2$ & $<0.05$ \\
No. of specimens examined & 98 & 115 & 114 & \\
D. theta & & & & \\
SCI (\% BW) & $1.4 \pm 0.7$ & $1.3 \pm 1.5$ & $1.2 \pm 1.18$ & $\mathrm{~ns}$ \\
No. of prey items per stomach & $8.7 \pm 4.1$ & $6.3 \pm 10.3$ & $5.8 \pm 4.5$ & $\mathrm{~ns}$ \\
No. of prey species per stomach & $4.4 \pm 1.7$ & $2.3 \pm 1.2$ & $2.0 \pm 1.1$ & $\ll 0.0001$ \\
Stomach fullness & $3.6 \pm 0.7$ & $2.3 \pm 1.3$ & $2.1 \pm 1.2$ & $\ll 0.0001$ \\
State of digestion & $3.2 \pm 0.4$ & $2.9 \pm 1.1$ & $2.5 \pm 1.1$ & $<0.001$ \\
No. of specimens examined & 12 & 89 & 118 & \\
S. leucopsarus & & & & \\
SCI (\% BW) & $1.9 \pm 1.8$ & $1.9 \pm 2.2$ & $1.5 \pm 1.9$ & $\mathrm{~ns}$ \\
No. of prey items per stomach & $3.7 \pm 2.1$ & $2.4 \pm 1.7$ & $1.7 \pm 0.9$ & $\ll 0.0001$ \\
No. of prey species per stomach & $1.9 \pm 1.0$ & $1.6 \pm 0.9$ & $1.3 \pm 0.5$ & $\ll 0.0001$ \\
Stomach fullness & $2.6 \pm 1.3$ & $2.2 \pm 1.5$ & $1.6 \pm 1.2$ & $\ll 0.0001$ \\
State of digestion & $3.3 \pm 0.7$ & $3.1 \pm 1.1$ & $2.6 \pm 1.1$ & $\ll 0.0001$ \\
No. of specimens examined & 104 & 103 & 96 & \\
\hline
\end{tabular}

Changes in feeding intensity of Diaphus theta were highly significant, with the most intense feeding observed in the smallest specimens (18-30 mm SL) and the lowest values recorded in specimens of 31-60 mm SL. Significant variation was also seen in the number of species ingested per stomach and in the stomach fullness index, with the highest values observed in the smallest size classes. Variations in the state of digestion and number of prey items per stomach were negligible.

All feeding parameters except stomach fullness index were significantly different between size classes in Stenobrachius leucopsarus, with the most significant variations in mean number of prey items and number of prey species ingested per stomach. Both of these parameters were greatest at intermediate sizes (31-60 $\mathrm{mm} \mathrm{SL}$ ). Less important were changes in feeding intensity and state of digestion of stomach contents, with SCI values generally decreasing with growth and state of digestion showing an opposite trend (Table 6).

\section{DISCUSSION}

Numerous studies worldwide have reported lanternfishes as major consumers of zooplankton in midwater communities (Hopkins \& Baird 1977, Hopkins \& Gartner 1992, Pakhomov et al. 1996, Brodeur \& Yamamura 2005). The 3 myctophids examined in our study fed almost exclusively on zooplankton. The only exception to this pattern occurred in the largest specimens of Tarletonbeania crenularis, which occasionally had fish remains in their stomachs. The fish consumed by $T$. crenularis was tentatively identified as Lipolagus ochotensis, a common midwater bathylagid found off Oregon.

It is relatively well established that trophic competition in myctophid communities can be significantly reduced through both inter- and intraspecific resource partitioning (Hopkins \& Gartner 1992, Gartner et al. 1997), and recent reports have indicated differential feeding patterns in lanternfish larvae as well (Conley \& Hopkins 2004, Sassa \& Kawaguchi 2005).

In our study, the most common and abundant euphausiid in oceanic waters off Oregon, Euphausia pacifica, was by far the most important prey for all 3 species based on IRI val- 
Table 6. Tarletonbeania crenularis, Diaphus theta, and Stenobrachius leucopsarus. Variability in feeding parameters between different size groups (SL) of 3 myctophids (mean \pm SD). SCI: stomach content index

\begin{tabular}{|c|c|c|c|c|c|c|c|}
\hline T. crenularis & $24-30 \mathrm{~mm}$ & $31-40 \mathrm{~mm}$ & $41-50 \mathrm{~mm}$ & $51-60 \mathrm{~mm}$ & $61-70 \mathrm{~mm}$ & $71-80 \mathrm{~mm}$ & $\mathrm{p}$ \\
\hline $\mathrm{SCI}(\%)$ & $3.1 \pm 2.6$ & $2.0 \pm 2.7$ & $2.9 \pm 2.6$ & $2.6 \pm 3.0$ & $2.5 \pm 2.9$ & $5.3 \pm 4.7$ & ns \\
\hline No. of prey items per stomach & $12.6 \pm 16.4$ & $21.3 \pm 32.1$ & $10.5 \pm 11.7$ & $21.8 \pm 52.7$ & $12.3 \pm 19.1$ & $10.5 \pm 10.4$ & ns \\
\hline No. of prey species per stomach & $2.0 \pm 1.0$ & $2.0 \pm 1.0$ & $2.0 \pm 1.0$ & $1.7 \pm 1.0$ & $1.4 \pm 0.8$ & $2.1 \pm 1.2$ & $<0.05$ \\
\hline Stomach fullness & $2.0 \pm 2.0$ & $2.5 \pm 1.4$ & $2.8 \pm 1.8$ & $2.7 \pm 1.8$ & $2.8 \pm 1.8$ & $3.8 \pm 1.6$ & ns \\
\hline State of digestion & $2.8 \pm 0.9$ & $2.6 \pm 1.0$ & $3.0 \pm 0.9$ & $3.1 \pm 1.2$ & $3.1 \pm 1.2$ & $3.2 \pm 0.9$ & $<0.05$ \\
\hline D. theta & $19-30 \mathrm{~mm}$ & $31-40 \mathrm{~mm}$ & $41-50 \mathrm{~mm}$ & $51-60 \mathrm{~mm}$ & $61-70 \mathrm{~mm}$ & & $\mathrm{p}$ \\
\hline SCI $(\%)$ & $2.6 \pm 1.0$ & $1.1 \pm 1.1$ & $1.0 \pm 0.9$ & $1.0 \pm 1.4$ & $1.4 \pm 1.7$ & & $\ll 0.0001$ \\
\hline No. of prey items per stomach & $8.8 \pm 3.5$ & $4.3 \pm 3.5$ & $5.9 \pm 6.9$ & $7.2 \pm 11.9$ & $3.7 \pm 3.1$ & & ns \\
\hline No. of prey species per stomach & $3.1 \pm 0.9$ & $2.0 \pm 1.2$ & $2.4 \pm 1.5$ & $2.3 \pm 1.2$ & $1.5 \pm 0.9$ & & $\ll 0.0001$ \\
\hline Stomach fullness & $2.8 \pm 1.2$ & $2.2 \pm 1.2$ & $2.2 \pm 1.2$ & $1.9 \pm 1.1$ & $2.6 \pm 1.6$ & & $<0.01$ \\
\hline State of digestion & $2.8 \pm 0.9$ & $2.7 \pm 0.8$ & $2.6 \pm 1.1$ & $2.5 \pm 1.3$ & $2.8 \pm 1.2$ & & ns \\
\hline S. leucopsarus & $18-30 \mathrm{~mm}$ & $31-40 \mathrm{~mm}$ & $41-50 \mathrm{~mm}$ & $51-60 \mathrm{~mm}$ & $61-74 \mathrm{~mm}$ & & $\mathrm{p}$ \\
\hline SCI $(\%)$ & $2.4 \pm 2.5$ & $1.8 \pm 1.9$ & $1.6 \pm 1.8$ & $1.7 \pm 1.9$ & $0.5 \pm 0.5$ & & $<0.05$ \\
\hline No. of prey items per stomach & $1.6 \pm 1.1$ & $3.3 \pm 2.0$ & $2.7 \pm 2.0$ & $2.3 \pm 1.5$ & $1.7 \pm 1.0$ & & $\ll 0.0001$ \\
\hline No. of prey species per stomach & $1.2 \pm 0.4$ & $1.8 \pm 0.9$ & $1.7 \pm 1.0$ & $1.5 \pm 0.6$ & $1.1 \pm 0.3$ & & $<0.0001$ \\
\hline Stomach fullness & $1.9 \pm 1.0$ & $2.2 \pm 1.3$ & $2.2 \pm 1.4$ & $2.5 \pm 2.0$ & $2.2 \pm 1.6$ & & ns \\
\hline State of digestion & $2.6 \pm 0.9$ & $3.1 \pm 0.9$ & $3.1 \pm 1.1$ & $3.2 \pm 1.2$ & $3.1 \pm 1.5$ & & $<0.05$ \\
\hline
\end{tabular}

ues. This accorded with findings of earlier myctophid diet studies at similar latitudes in the Pacific, including those of Diaphus (Kosenok et al. 2006), Notoscopelus (Uchikawa et al. 2002), Stenobrachius (Moku et al. 2000, Balanov et al. 1995), and Triphoturus (Imsand 1981). At the same time, dietary differences are more apparent in smaller individuals of our 3 studied species, suggesting stronger competition and resource partitioning prior to the period when all species are able to consume larger, agile, and most abundant prey such as euphausiids.

The higher proportion of euphausiids in all 3 species during August generally agrees with observations of their peak of abundance during late summer (GómezGutiérrez et al. 2005). Alternatively, the mean lengths of August specimens of Diaphus theta were significantly greater than those examined in June and September. This may be another reason for the higher proportion of euphausiids consumed during August in this species, considering the patterns in ontogenetic diet shifts observed here and elsewhere (Tyler \& Pearcy 1975). However, this would not be the case for Tarletonbeania crenularis, in which the mean length of August specimens was not significantly different from those of either June or September.

Copepods were the next most important food category for Stenobrachius leucopsarus after euphausiids, similar to what was found for this species in both southern (Collard 1970, Cailliet 1972, Cailliet \& Ebeling 1990) and northern regions (Tyler \& Pearcy 1975,
Pearcy et al. 1979, Bosley et al. 2004) of the California Current. Interestingly, feeding studies from other regions (e.g. Bering Sea) have repeatedly shown a higher prevalence of copepod biomass in the diet of this species (Gorbatenko \& Il'inskii 1991, Balanov 1994). A recent study of $S$. leucopsarus in the Bering Sea suggested that copepods can be important prey items in some seasons (e.g. spring), whereas euphausiids are more important diet items later in the year (Tanimata et al. 2008).

The population of Stenobrachius leucopsarus off the coast of Oregon consists of non-migratory and vertically migrating individuals (Pearcy et al. 1979). Our data on the migrating portion of the S. leucopsarus population is consistent with earlier findings of ontogenetic diet shift in this species as well as total number of prey items in stomachs (Pearcy et al. 1979). However, Pearcy et al. (1979) recorded a noticeably higher number of copepod prey species, but this was likely due to their larger sample size, as well as their broader vertical coverage of the water column. Overall, copepods were the most species-rich group in all 3 myctophid species examined in our study, with each having 10 to 11 copepod taxa in their diet. In general, the copepod prey species represented a typical species mixture from the offshore copepod assemblage consisting of both Transition Zone species and temperate-subtropical neritic taxa (Morgan et al. 2003).

Based on IRI indices, selectivity for different types of prey was more evenly distributed in Tarletonbeania 
crenularis and Diaphus theta, indicating a more balanced overall food spectrum than in Stenobrachius leucopsarus, which had only 2 major prey categories. Beyond the predominance of Euphausia pacifica, which had very similar IRI values in both $T$. crenularis and $D$. theta, the 2 species showed some differences in diet, with larvaceans, hyperiids, and salps (in decreasing order of importance) occurring more in T. crenularis and salps, copepods, hyperiids, and larvaceans in $D$. theta. Of the less common prey categories, D. theta also showed a clear selectivity for shelled zooplankton, such as ostracods and the pteropod Limacina helicina.

Night-time vertical distribution of 3 dominant myctophid species off Oregon can be different in terms of their maximum abundance (Pearcy 1964). In general, Tarletonbeania crenularis showed the shallowest distribution, with greatest number of individuals recorded above $10 \mathrm{~m}$, Diaphus theta was most abundant between 10 and $25 \mathrm{~m}$, and Stenobrachius leucopsarus between 25 and $30 \mathrm{~m}$. Although inferred from nonclosing fishing gear, these data suggest vertical partitioning of the night-time habitat of these fishes. Such habitat subdivision may affect their night-time feeding, if zooplankton prey species display similar patterns of water column partitioning. However, available information indicates that these lanternfishes are likely to find similar assemblages of prey during their night-time presence in the mixed layer (Mackas \& Tsuda 1999).

In view of the differences in feeding between these myctophids, we also note that they belong to 2 different eco-morphological types, according to an informal classification based on in situ observations and estimates of swimming ability (Barham 1971). These include the so-called active myctophids, characterized by the presence of a well-developed, gas-filled swimbladder (can be absent in some species) and a relatively low lipid content. Other features of the active lanternfish type include a firm body, often with a slender caudal peduncle, large eyes, and silvery scales. These species are active diel vertical migrants and strongly follow isolumes. Some examples of active myctophids include Myctophum, Protomyctophum, Tarletonbeania, and Benthosema (Barham 1971, Butler \& Pearcy 1972, Neighbors \& Nafpaktitis 1982). In contrast, inactive myctophids are characterized by a dark body with a deep caudal peduncle, flabby muscles, and relatively small eyes. These species can also migrate to the surface at night, but usually stay deeper and are not attracted by light. Inactive lanternfishes such as Stenobrachius leucopsarus, Triphoturus mexicanus, and numerous species of Lampanyctus are lessactive swimmers, have a much higher body lipid content, and often have a fat-invested swimbladder. Species of Diaphus do not fall readily into either of the
2 types, occupying a somewhat intermediate position (Bekker 1983). Subsequent studies provided more evidence that active and inactive myctophids differ significantly by lipid and water content and also by the type of lipids they accumulate (wax esters versus triglycerides; Neighbors \& Nafpaktitis 1982).

In a typical inactive myctophid, such as Stenobrachius leucopsarus, lipids are composed of large quantities of low-density wax esters, which, coupled with a high body-water content, serve as a buoyancy mechanism (Butler \& Pearcy 1972, Neighbors \& Nafpaktitis 1982). In contrast, triglyceride-rich Diaphus theta uses stored lipids as an energy reserve and not for buoyancy control, which indicates its need for more active swimming (Neighbors \& Nafpaktitis 1982). Tarletonbeania crenularis, as a typical active myctophid, is characterized by firm muscles and skin, nondeciduous scales, and the general appearance of a good swimmer. Morphological differences between the active $T$. crenularis and the inactive $S$. leucopsarus were very apparent upon visual examination of specimens collected from the Nordic trawl: $T$. crenularis showed the best resistance to abrasion in the Nordic trawl cod-end and was often retrieved in excellent condition, whereas the lipid-rich, watery bodies of S. leucopsarus suffered the most damage, with most specimens devoid of skin and showing signs of evisceration. Specimens of $D$. theta showed a somewhat intermediate condition during sampling.

Our results suggest that variations in diet among these lanternfishes are a reflection of their structural morphology, differing energy requirements, and general life strategies. In our study, the active myctophid Tarletonbeania crenularis consumed significantly higher amounts of fast-moving, protein-rich plankton, such as euphausiids and hyperiid amphipods. Stenobrachius leucopsarus consumed the least biomass of these 3 prey taxa, and Diaphus theta was intermediate between the other 2 . The higher feeding activity of $D$. theta compared to $S$. leucopsarus was also noted in an earlier study (Moku et al. 2000). Considering that species with stronger swimming abilities would presumably have a more extensive foraging range, it is not surprising that $T$. crenularis showed the highest diversity of prey, followed by D. theta and S. leucopsarus; however, these differences were not pronounced.

In the present study, the more active myctophids Tarletonbeania crenularis and Diaphus theta consumed significant quantities of salps, a feeding resource apparently containing up to $80 \%$ protein (\% of total organic content, $6.6 \%$ dry weight), but very little lipid $(7.6 \%$ of total organic content, $0.6 \%$ dry weight; Madin et al. 1981). In the Atlantic Ocean, another component of the active group, Ceratoscopelus warmingii, was found to prey heavily on salps (Kinzer \& 
Schulz 1985), which comprised $12 \%$ by number of the prey items consumed, a value very similar to our data for T. crenularis. In sharp contrast, inactive Stenobrachius leucopsarus completely avoided eating salps during all months investigated. The most recent study of $S$. leucopsarus in the western part of the North Pacific also did not list salps as part of the diet of this species (Tanimata et al. 2008).

Salp feeding by the active myctophids Tarletonbeania crenularis and Diaphus theta is rather new information, since gelatinous zooplankton were not previously reported as a significant food component in these species (Tyler \& Pearcy 1975). Similarly, the diet of $D$. theta off the Kuril Islands in Russia contained only a minor proportion of salps (Kosenok et al. 2006). On the other hand, salps have often been categorized as unidentified gelatinous material (Mauchline \& Gordon 1983), thus obscuring their actual proportions in diets. The significance of salps in feeding has been reported for a number of fish groups, and their importance was stressed for continental slopes and regions around seamounts, islands, and underwater rises, where concentrations can be particularly high (Kashkina 1986). A number of salp species were present off Oregon throughout the year, with maximum abundances for some species (Salpa fusiformis, Iasis zonaria) recorded during intense summer upwelling conditions, while other species occurred in higher densities during winter (Thalia democratica, Pegea confederata; Hubbard \& Pearcy 1971).

Recent modeling of seasonal food webs on Oregon's inner shelf indicates that large gelatinous zooplankton such as jellyfishes can play a significant role as zooplankton consumers. At the same time, large jellyfishes are rarely consumed by potential predators, leading to a significant diversion of zooplankton production away from higher trophic levels (Ruzicka et al. 2007). Away from the coastal zone, where abundances of smaller gelatinous organisms such as salps or larvaceans are more pronounced, the situation can be drastically different. Considering the extreme growth rates of these organisms (Heron 1972), short generation times, and high fecundities (Alldredge \& Madin 1982), as well as their apparent consumption by myctophids in the NCC, models of the pelagic ecosystem will need to consider the energy pathways between these components of the oceanic environment.

The high lipid content, watery muscle tissue, and fatfilled swimbladder suggest less efficient swimming in Stenobrachius leucopsarus, and are likely the main causes for its selectivity of less active, slower-moving prey. We observed that $S$. leucopsarus showed a marked preference for large, lipid-rich, deeperdwelling copepods such as Neocalanus ( $N$. cristatus and N. plumchrus), which, in terms of WW biomass, comprised over $50 \%$ of all copepod specimens identified. Similar selectivity for Neocalanus spp. by S. leucopsarus was noted in an earlier study off Oregon (Tyler \& Pearcy 1975) as well as in the western Pacific (Moku et al. 2000). Adult Neocalanus spp. are known to spend late summer, autumn, and early winter at depths of 400 to $2000 \mathrm{~m}$ (Miller et al. 1984, Mackas \& Tsuda 1999). Neocalanus copepods (all adults) found in $S$. leucopsarus stomachs showed a different degree of digestion and were likely consumed at depth prior to or during ascent to surface layers.

Many pelagic copepods contain large quantities of wax esters as energy reserves (Lewis 1967, FalkPetersen et al. 1987). For diapausing copepods, large sacs of wax esters are suggested as an adaptation for achieving neutral buoyancy in cold, deep waters, so they can minimize energy expenditure while maintaining depth (Lee et al. 2006). Similarly, wax esters are the principal constituents of lipids in Stenobrachius leucopsarus. A study on several myctophids suggested that wax esters in pelagic copepods of the genera Neocalanus and Eucalanus can be directly incorporated into the lipids of lanternfishes (Saito \& Murata 1998). This information may help to explain the selectivity for large, lipid-rich copepods and the avoidance of lipidpoor salps by $S$. leucopsarus. Another inactive myctophid, Lampanyctus alatus, in the eastern Gulf of Mexico showed a similar high selectivity for large, lipid-rich copepods of the genus Pleuromamma (Hopkins \& Baird 1985). Further observations on the feeding ecology of particular midwater species and/or ecological groups, put into the context of structural morphology, biochemical composition, and general lifestyles, are needed to better understand the ecomorphological correlates and trophic relationships in the mesoplagic zone.

The current study provides information on lanternfish feeding during summer and early autumn, but no work to date has addressed trophic interactions in this family during winter months. Although there is apparently little change in the offshore copepod communities off Oregon and Washington between summer and winter seasons (Morgan et al. 2003), temporal variation in abundance of other zooplankton groups could be quite pronounced, potentially affecting diet and other trophic characteristics of principal micronektonic fishes. Thus, future emphasis on lanternfish diel feeding chronology, daily rations, standing stocks, and abundance, along with zooplankton prey abundance in the environment, is required to better understand the feeding ecology of these fishes, their actual role as competitors to commercial species, and their overall importance in the oceanic food webs and ecosystem dynamics. 
Acknowledgements. We thank J. Phillips, T. Auth, R. Emmett, and P. Peterson for help in collecting the specimens at sea and J. Lamb and W. Peterson for assistance with identification of copepods. We are grateful to W. Pearcy, W. Peterson, T. Miller, E. Casillas, and 3 anonymous reviewers for constructive comments and valuable suggestions on an earlier version of the manuscript. A.S. was supported by a National Research Council postdoctoral fellowship funded by NOAA's Stock Assessment Improvement Program.

\section{LITERATURE CITED}

Alldredge AL, Madin LP (1982) Pelagic tunicates: unique herbivores in the marine plankton. Bioscience 32:655-663

Balanov AA (1994) Feeding habits of the most abundant mesopelagic fishes in the Bering Sea. Vopr Ikhtiol 34:252-259

Balanov AA, Gorbatenko KM, Efimkin AY (1995) Diel dynamics of feeding in mesopelagic fishes of the Bering Sea during autumn. Russ J Mar Biol 21:106-111

Barham EG (1971) Deep-sea fishes: lethargy and vertical orientation. In: Farquhar GB (ed) Proc Int Symp Biol Sound Scattering Layers. Maury Center for Ocean Science, Washington DC, Rep Mc-005, p 100-118

Barth JA, Pierce SD, Cowles TJ (2005) Mesoscale structure and its seasonal evolution in the northern California Current System. Deep-Sea Res II 52:5-28

Beamish RJ, Leask KD, Ivanov OA, Balanov AA, Orlov AM, Sinclair B (1999) The ecology, distribution, and abundance of midwater fishes of the Subarctic Pacific. Prog Oceanogr 43:399-442

Bekker VE (1983) Myctophid fishes of the world ocean. Nauka, Moscow (in Russian)

Bosley KL, Lavelle JW, Brodeur RD, Wakefield WW, Emmett RL, Baker ET, Rehmke KM (2004) Biological and physical processes in and around Astoria Submarine Canyon, Oregon, USA. J Mar Syst 50:21-37

Brickley PJ, Thomas AC (2004) Satellite-measured seasonal and interannual chlorophyll variability in the Northeast Pacific and Coastal Gulf of Alaska. Deep-Sea Res II 51: 229-245

Brodeur RD, Yamamura O (eds) (2005) Micronekton of the North Pacific. PICES Sci Rep No. 30. North Pacific Marine Science Organization, Sidney, BC

Brodeur RD, Pearcy WG, Ralston S (2003) Abundance and distribution patterns of nekton and micronekton in the Northern California Current Transition Zone. J Oceanogr 59:515-535

Brodeur RD, Seki MP, Pakhomov EA, Suntsov AV (2005) Micronekton - what are they and why they are important? PICES Press 14:7-11

Butler JL, Pearcy WG (1972) Swimbladder morphology and specific gravity of myctophids off Oregon. J Fish Res Board Can 29:1145-1150

Cailliet GM (1972) The study of feeding habits of two marine fishes in relation to plankton ecology. Trans Am Microsc Soc 91:88-89

Cailliet GM, Ebeling AW (1990) The vertical distribution and feeding habits of two common midwater fishes (Leuroglossus stilbius and Stenobrachius leucopsarus) off Santa Barbara. Calif Coop Ocean Fish Invest Rep 31:106-123

Chelton DB, Bernal PA, McGowan JA (1982) Large-scale interannual physical and biological interaction in the California Current. J Mar Res 40:1095-1125

Clarke TA (1973) Some aspects of the ecology of lanternfishes (Myctophidae) in the Pacific Ocean near Hawaii. Fish Bull (Wash DC) 71:401-434
Clarke KR, Gorley RN (2001) Primer v5: user manual/tutorial. PRIMER-E Ltd, Plymouth

Clarke KR, Green RH (1988) Statistical design and analysis for a 'biological effects' study. Mar Ecol Prog Ser 46: 213-226

Collard SB (1970) Forage of some eastern Pacific midwater fishes. Copeia 1970:348-354

Conley WJ, Hopkins TL (2004) Feeding ecology of lanternfish (Pisces: Myctophidae) larvae: prey preferences as reflection of morphology. Bull Mar Sci 75:361-379

- Emmett RL, Brodeur RD, Orton PM (2004) The vertical distribution of juvenile salmon and associated fishes in the Columbia River plume. Fish Oceanogr 13:392-402

> Falk-Petersen S, Sargent JR, Tande K (1987) Lipid composition of zooplankton in relation to the sub-Arctic food web. Polar Biol 8:115-120

Field JC, Francis RC, Aydin KY (2006) Top-down and bottomup dynamics: linking a fisheries-based ecosystem model with climate hypotheses in the Northern California Current. Prog Oceanogr 68:238-270

Gartner JV Jr, Crabtree RE, Sulak KJ (1997) Feeding at depth. In: Randall D, Farrell A (eds) Fish physiology. Deep-sea fishes, Vol 16. Academic Press, San Diego, CA, p 115-193

Gjøsaeter J, Kawaguchi K (1980) A review of the world resources of mesopelagic fish. FAO Fish Tech Pap 193: $1-151$

> Gómez-Gutiérrez J, Peterson WT, Miller CB (2005) Crossshelf life-stage segregation and community structure of the euphausiids off central Oregon (1970-1972). DeepSea Res II 52:289-315

Gorbatenko KM, Il'inskii EN (1991) Feeding of common mesopelagic fishes of the Bering Sea. Vopr Ikhtiol 31: 816-821

Gordon JDM, Nishida S, Nemoto T (1985) The diet of mesopelagic fish from the Pacific coast of Hokkaido, Japan. J Oceanogr 41:89-97

- Heron AC (1972) Population ecology of a colonizing species: the pelagic tunicate Thalia democratica I. Individual growth rates and generation time. Oecologia 10:269-293

Hopkins TL, Baird RC (1977) Aspects of the feeding ecology of oceanic midwater fishes. In: Andersen NR, Zahuranec BJ (eds) Oceanic sound scattering prediction. Plenum Press, New York, p 325-360

Hopkins TL, Baird RC (1985) Aspects of the trophic ecology of the mesopelagic fish Lampanyctus alatus (Family Myctophidae) in the eastern Gulf of Mexico. Biol Oceanogr 3: 285-313

> Hopkins TL, Gartner JV (1992) Resource-partitioning and predation impact of a low-latitude myctophid community. Mar Biol 114:185-197

Hubbard LT, Pearcy WG (1971) Geographic distribution and abundance of Salpidae off the Oregon Coast. J Fish Res Board Can 28:1831-1836

> Imsand S (1981) Comparison of the food of Triphoturus mexicanus and T. nigrescens, two lanternfishes of the Pacific Ocean. Mar Biol 63:87-100

Kashkina AA (1986) Feeding of fishes on salps (Tunicata, Thaliacea). J Ichthyol 26:57-64

Kinzer J, Schulz K (1985) Vertical distribution and feeding patterns of midwater fish in the central equatorial Atlantic I. Myctophidae. Mar Biol 85:313-322

Kosenok NS, Chuchukalo VI, Savynikh VF (2006) The characteristics of feeding of Diaphus theta (Myctophidae) in the northwest part of the Pacific Ocean in the summerautumn period. J Ichthyol 46:606-612

Lee RF, Hagen W, Kattner G (2006) Lipid storage in marine zooplankton. Mar Ecol Prog Ser 307:273-306 
Lewis RW (1967) Fatty acid composition of some marine animals from various depths. J Fish Res Board Can 24: 1101-1115

Mackas DL, Tsuda A (1999) Mesozooplankton in the eastern and western subarctic Pacific: community structure, seasonal life histories, and interannual variability. Prog Oceanogr 43:335-363

Madin LP, Cetta CM, McAlister VL (1981) Elemental and biochemical composition of salps (Tunicata: Thaliacea). Mar Biol 63:217-226

Mauchline J, Gordon JDM (1983) Diets of clupeoid, stomiatoid and salmonoid fish of the Rockall Trough, northeastern Atlantic Ocean. Mar Biol 77:67-78

McGowan JA, Cayan DR, Dorman LM (1998) Climate-ocean variability and ecosystem response in the northeast Pacific. Science 281:210-217

Merrett NR, Roe HSJ (1974) Patterns and selectivity in the feeding of certain midwater fishes. Mar Biol 28:115-126

Miller CB, Frost BW, Batchelder HP, Clemons MJ, Conway RE (1984) Life histories of large, grazing copepods in a Subarctic Ocean Gyre: Neocalanus plumchrus, Neocalanus cristatus, and Eucalanus bungii in the North Pacific. Prog Oceanogr 13:201-243

Moku M, Kawaguchi K, Watanabe H, Ohno A (2000) Feeding habits of three dominant myctophid fishes, Diaphus theta, Stenobrachius leucopsarus and S. nannochir, in the subarctic and transitional waters of the western North Pacific. Mar Ecol Prog Ser 207:129-140

Morgan CA, Peterson WT, Emmett RL (2003) Onshore-offshore variations in copepod community structure off the Oregon coast during the summer upwelling season. Mar Ecol Prog Ser 249:223-236

Neighbors MA, Nafpaktitis BG (1982) Lipid compositions, water contents, swimbladder morphologies and buoyancies of nineteen species of midwater fishes (18 myctophids and 1 neoscopelid). Mar Biol 66:207-215

Nishimura A, Nagasawa K, Asanuma T, Aoki H, Kubota T (1999) Age, growth, and feeding habits of lanternfish, Stenobrachius leucopsarus (Myctophidae), collected from the near-surface layer in the Bering Sea. Fish Sci 65: $11-15$

Pakhomov EA, Perissinotto R, McQuaid CD (1996) Prey composition and daily rations of myctophid fishes in the Southern Ocean. Mar Ecol Prog Ser 134:1-14

Editorial responsibility: Peter Verity,

Savannah, Georgia, USA
Pearcy WG (1964) Some distributional features of mesopelagic fishes off Oregon. J Mar Res 22:83-102

Pearcy WG (1977) Variations in abundance of sound scattering animals off Oregon. In: Andersen NR, Zahuranec BJ (eds) Oceanic sound scattering prediction. Plenum Press, New York, p 647-666

$>$ Pearcy WG, Lorz HV, Peterson WT (1979) Comparison of the feeding habits of migratory and non-migratory Stenobrachius leucopsarus (Myctophidae). Mar Biol 51:1-8

Peterson WT, Schwing FB (2003) A new climate regime in northeast Pacific ecosystems. Geoph Res Lett 30:6-1-6-4

Pinkas L, Oliphant MS, Iverson ILK (1971) Food habits of albacore, bluefin tuna, and bonito in California waters. Calif Fish Game 152:1-105

Ruzicka JJ, Brodeur RD, Wainwright TC (2007) Seasonal food web models for the Oregon inner-shelf ecosystem: investigating the role of large jellyfish. Calif Coop Ocean Fish Invest Rep 48:106-128

Saito H, Murata M (1998) Origin of the monoene fats in the lipid of midwater fishes: relationship between the lipids of myctophids and those of their prey. Mar Ecol Prog Ser 168: 21-33

> Sassa C, Kawaguchi K (2005) Larval feeding habits of Diaphus theta, Protomyctophum thompsoni, and Tarletonbeania taylori (Pisces: Myctophidae) in the transition region of the western North Pacific. Mar Ecol Prog Ser 298:261-276

> Tanimata N, Yamamura O, Sakurai Y, Azumaya T (2008) Dietary shift and feeding intensity of Stenobrachius leucopsarus in the Bering Sea. J Oceanogr 64:185-194

Tyler HR, Pearcy WG (1975) The feeding habits of three species of lanternfishes (family Myctophidae) off Oregon, USA. Mar Biol 32:7-11

Uchikawa K, Yamamura O, Kitagawa D, Sakurai Y (2002) Diet of the mesopelagic fish Notoscopelus japonicus (Family: Myctophidae) associated with the continental slope off the Pacific coast of Honshu, Japan. Fish Sci 68:1034-1040

Watanabe H, Kawaguchi K, Hayashi A (2002) Feeding habits of juvenile surface-migratory myctophid fishes (family Myctophidae) in the Kuroshio region of the western North Pacific. Mar Ecol Prog Ser 236:263-272

> Williams A, Koslow JA, Terauds A, Haskard K (2001) Feeding ecology of five fishes from the mid-slope micronekton community off southern Tasmania, Australia. Mar Biol 139: $1177-1192$

Submitted: December 12, 2007; Accepted: August 1, 2008 Proofs received from author(s): November 20, 2008 